\title{
SERIAL FOLLOW UP OF SOLUBLE THROMBOMODULIN LEVELS IN PATIENTS WITH SYSTEMIC LUPUS ERYTHEMATOSUS
}

\author{
Pavel Horák ${ }^{\mathrm{a}}$, Zuzana Heřmanováb, Jarmila Vašíčkováa ${ }^{\mathrm{a}}$ Zdeněk Pospíšil ${ }^{\mathrm{a}}$, Ladislav Faltýnek ${ }^{\mathrm{a}}$, \\ Vlastimil Ščudla ${ }^{a}$
}

a III. Department of Internal Medicine, Faculty of Medicine and Faculty Hospital, Palacký University, 77520 Olomouc, Czech Republic

b Department of Clinical Immunology, Faculty Hospital, 77520 Olomouc, Czech Republic

Received September 24, 2000

Key words: Systemic lupus erythematosus / Thrombomodulin / Disease activity

Plasma thrombomodulin (TM), a marker of disease activity and endothelial damage, was measured in follow up of patients with systemic lupus erythematosus (SLE). Plasma levels of TM were measured by ELISA method using the mouse antithrombomodulin monoclonal antibody in the group of 52 lupus patients. Disease activity was assessed by European Consensus Lupus Activity Measurement (ECLAM) and levels of anti-dsDNA antibodies and $\mathrm{C} 3$ and $\mathrm{C} 4$ complement components were investigated. Correlation between thrombomodulin plasma levels and disease activity index was found $(r=0.69 \mathrm{p}=0.00001)$. Stable and low levels of TM were found in the subgroup of patients with low stabile disease $\bar{x}=32.0( \pm 11.56) \mathrm{ng} / \mathrm{ml}$ with no trend to significant change. In the subgroup with high and rising disease activity the TM levels were initially $\bar{x}=51.9( \pm 49.0) \mathrm{ng} / \mathrm{ml}$ with trend to further increase $(\overline{\mathrm{x}}=72.66 \pm 44.0$ and $98.14 \pm 71.4 \mathrm{ng} / \mathrm{ml})$ at the following measurements. In the subgroup with decreasing disease activity levels of $\mathrm{TM} \overline{\mathrm{x}}=62.8 \pm 49$ dropped to $38.75 \pm 21.30$ and $40.45 \pm 17.15 \mathrm{ng} / \mathrm{ml}$, which was statistically significant $(\mathrm{p}=0.02)$. Correlation between TM and anti ds-DNA levels was not significant. TM seems to be sensitive marker of disease activity independent from anti-dsDNA antibody titer suitable for monitoring the disease activity as the part of the laboratory panel.

\section{INTRODUCTION}

Vasculitis plays an essential role in the SLE pathogenesis. Many manifestations of systemic lupus erythematosus, and among them also the most serious, lupus nephritis and CNS involvement, are closely related to vasculitic damage. The classical marker of SLE activity, anti-dsDNA antibody, reflects the autoimmune activity of B cells, but is not directly associated with the vasculitic damage. Thrombomodulin (TM) is a glycoprotein, present on intact endothelial cell surfaces, that plays a major role in the protein $\mathrm{C}$ activation anticoagulant system. TM is transmembrane receptor of thrombin ${ }^{1}$. Once thrombin is bound to TM, it loses its coagulant activity and becomes activator of protein $\mathrm{C}$. Its role in SLE pathogenesis remains unknown. Plasma TM is produced by injured endothelium, and seems to be closely related to endothelial cell damage. In previous studies thrombomodulin was suggested as a possible new marker of disease activity or therapeutic response in $\mathrm{SLE}^{2,3}$.

Objective of this study was to measure TM levels in follow up of patients with SLE and to compare it to some other disease activity markers (anti-dsDNA antibody, C3, C4) and to ECLAM index of disease activity (European Consensus Lupus Activity Measurement) ${ }^{4}$.

\section{MATERIAL AND METHODS}

\section{Patients}

Thrombomodulin was measured in the group of 52 patients, 50 of them females, mean age 39 years (20-73), mean duration of disease 4 years (0-20), who all fulfilled at least 4 criteria of SLE according to $\mathrm{ACR}^{5}$. Serum thrombomodulin was measured at 3 time points during six months. Patients received following treatment: Twelve patients received corticosteroid in low dose (Prednison $\leq 7.5 \mathrm{mg} / \mathrm{day}$ ), four patients antimalarials, one patient Methotrexate and one patient Azathioprine as the single treatment. Rest of the group received the combined drug treatment: Five patients antimalarials and low dose corticosteroid, one patient Methotrexate and corticosteroid $>7.5 \mathrm{mg} / \mathrm{day}$, ten patients Azathioprine and corticosteroid $>7.5 \mathrm{mg} / \mathrm{day}$, ten patients Cyclophosphamide with corticosteroid $>7.5 \mathrm{mg} /$ day and eight patients Cyclosporin A with corticosteroid $>7.5 \mathrm{mg} /$ day. All patients treated with Cyclophosphamide (10) had active lupus nephritis, four of these were classified as III.B, two were IV.B according to WHO classification, the renal biopsy was not performed in four patients. Five patients treated with Cyclosporin A (8) had the lupus nephritis, which documented by histology in 3 patients (one III.A, one IV.B, and one V.A). 


\begin{abstract}
Methods
Serum levels of soluble thrombomodulin were measured by ELISA method (set Diagnostica Stago, Asnieres, France). In this assay, a solid support is coated with specific mouse monoclonal antibody, which binds thrombomodulin in the assay standard or in the patient's sample. The bound thrombomodulin is revealed by the use of second mouse antithrombomodulin monoclonal antibody labeled with horseradish peroxidase, which binds to another antigenic determinant of the thrombomodulin molecule that is at the distance away from the first one. The bound enzymatic activity is then demonstrated by its oxidative action on the substrate ortho-phenylenediamine (OPD) in the presence of urea peroxide. After the reaction has been stopped by the addition of sulphuric acid, the obtained coloration is measured at 492nm. Anti-dsDNA antibodies were detected also by ELISA (set Ubi-Magiwel, Mountain View, CA, USA) with following evaluation: $<30 \mathrm{IU} / \mathrm{ml}$ negative, $30-40 \mathrm{IU} / \mathrm{ml}$ borderline positive, $>40 \mathrm{IU} / \mathrm{ml}$ positive. Levels of C3 and C4 components of complement were measured by nephelometry using the diagnostic antiserum Behringer AG, Marburg, Germany, with normal values for C3 $0.65-1.45 \mathrm{~g} / \mathrm{l}$, for C4 $0.18-0.50 \mathrm{~g} / \mathrm{l}$.
\end{abstract}

\section{Statistic}

Pearson correlation test and ANOVA test were used for statistical evaluation of results.

\section{RESULTS}

The range of TM plasma levels in 52 patients was from 7 to $202 \mathrm{ng} / \mathrm{ml}$ with mean value $49.7 \mathrm{ng} / \mathrm{ml}$. The positive correlation was found between TM plasma levels and ECLAM index $(r=0.69, p=0.00001)$ in the group as the whole (Figure 1). The correlation with TM was not detected for anti-dsDNA, C3 or C4 in the whole group. ECLAM index correlated with anti ds-DNA antibodies $(\mathrm{r}=0.48, \mathrm{p}=0.003), \mathrm{C} 3(\mathrm{r}=-0.60, \mathrm{p}=0.002)$ and $\mathrm{C} 4(\mathrm{r}=-0.52, \mathrm{p}=0.003)$.

Patients were then divided into three subgroups according to the ECLAM index:

1. Stabilized disease activity (ECLAM index $\leq 3$ and difference in ECLAM index during the period of follow up $\leq 1$ ), subgroup A 22 patients.

2. High and/or rising activity (ECLAM index $>3$ and/or difference $>+1$ in the second and third ECLAM scores), subgroup B 12 patients.

3. Declining activity (ECLAM $>3$ and difference between the initial and subsequent ECLAM scores $\leq-1$ ) subgroup C 18 patients (Table 1).

Serum thrombomodulin levels were analyzed in subgroups A, B, C (Table 2). In the subgroup A with stable ECLAM index TM mean values were $32 \mathrm{ng} / \mathrm{ml}$ in first (I.), $37.9 \mathrm{ng} / \mathrm{ml}$ in the second (II.) and $36.5 \mathrm{ng} / \mathrm{ml}$ in the third (III.) series of measurements (Figure 2A). In subgroup B with high or rising ECLAM score it was (I.) $51.9 \mathrm{ng} / \mathrm{ml}$, (II.) $72.66 \mathrm{ng} / \mathrm{ml}$ and (III.) $98.14 \mathrm{ng} / \mathrm{ml}$ (Fi- gure 2B). Subgroup $\mathrm{C}$ with declining ECLAM index showed values of TM (I.) $62.8 \mathrm{ng} / \mathrm{ml}$, (II.) $38.75 \mathrm{ng} / \mathrm{ml}$ and (III) $40.45 \mathrm{ng} / \mathrm{ml}$ (Figure 2C). Graphic comparison of these three subgroups is in the Figure 2D.

Using the analysis of variance ANOVA the significant difference in serum thrombomodulin levels was found during the first series of measurements between following subgroups: $\mathrm{A}$ and $\mathrm{B}(\mathrm{p}=0.01), \mathrm{A}$ and $\mathrm{C}$ $(p=0.02)$. No significant difference was found between $\mathrm{B}$ and $\mathrm{C}$. In the second series of measurements there was significant difference between $A$ and $B(p=0.025)$, $B$ and $C(p=0.01)$ and no difference between $A$ and $C$. In the third series of measurements statistical significant difference was between A and B ( $p=0.03), B$ and $C(p=0.001)$, non significant difference then between $\mathrm{A}$ and C. A significant difference was also observed between and I. and II., I. and III. series of TM measurements in subgroup $C(p=0.02)$.

Anti-dsDNA levels showed also three different trends among the patients group:

1. Low (stabilized) negative titer - subgroup D (antidsDNA $\leq 40 \mathrm{IU} / \mathrm{ml}), 26$ patients

2. High and/or rising titer subgroup E (anti-dsDNA $>40 \mathrm{IU} / \mathrm{ml}$ during the follow up or an initial value $\leq 40$, then rising $>40 \mathrm{IU} / \mathrm{ml}$ in subsequent tests), 16 patients

3. Declining titer subgroup F (initially $>40$, then dropping under $40 \mathrm{IU} / \mathrm{ml}$ ), 10 patients (Table 1 ).

In subgroup D (with low stable anti ds-DNA levels) mean values of TM were I. $33.52 \mathrm{ng} / \mathrm{ml}$, II. $47.0 \mathrm{ng} / \mathrm{ml}$, III. $41 \mathrm{ng} / \mathrm{ml}$. In subgroup $\mathrm{E}$ with high or rising antidsDNA titer the following mean values of TM were found: I. $56.7 \mathrm{ng} / \mathrm{ml}$, II. $61.88 \mathrm{ng} / \mathrm{ml}$, III. $79.8 \mathrm{ng} / \mathrm{ml}$. Subgroup F characterized by declining anti-dsDNA levels had in the I. series 58.0, in II. $34.5 \mathrm{ng} / \mathrm{ml}$ and in III. $31.25 \mathrm{ng} / \mathrm{ml}$ (Table 2, Figure 3). Statistical analysis of TM levels has shown significant difference between subgroups $\mathrm{D}$ and $\mathrm{E}(\mathrm{p}=0.01)$, while no difference was between $\mathrm{D}$ and $\mathrm{F}, \mathrm{E}$ and $\mathrm{F}$ subgroups. In the second series of measurements there was no significant difference between subgroups D, E, F. In the third series of measurements statistical significant difference was between subgroups $\mathrm{D}$ and $\mathrm{F}$ on one side and $\mathrm{E}$ on the other side $(p=0.04)$, non significant difference then between D and F subgroups. Significant difference was observed between and I. and II., I. and III. series of TM measurement in subgroup $\mathrm{F}(\mathrm{p}=0.02)$.

In the subgroup of 15 patients with lupus nephritis (LN) the mean values of TM were $78.33 \mathrm{ng} / \mathrm{ml}$, antidsDNA mean levels $90.07 \mathrm{IU} / \mathrm{ml}$, ECLAM mean score 5 in the first series of measurement, in the second $\mathrm{TM}=66.06 \mathrm{ng} / \mathrm{ml}$, anti-dsDNA 73.49, ECLAM 3.3 and in the third series mean values of TM were 73.12, antidsDNA 75.44 and of ECLAM index 3.4, while in all patients without lupus nephritis TM mean level was $31.64 \mathrm{ng} / \mathrm{ml}$, mean anti-dsDNA titer $40 \mathrm{IU} / \mathrm{ml}$ and mean ECLAM index 2.2.

Using ANOVA analysis of TM levels, LN subgroup was statistically different from the subgroups with stable 
low disease activity ( $\mathrm{A}$ and $\mathrm{D}, \mathrm{p}=0.02$ ) as well as from the second and third measurement in the subgroups with declining disease activity $(\mathrm{C}$ and $\mathrm{F}, \mathrm{p}=0.02)$. No significant differences were in TM levels between lupus nephritis subgroup and subgroups with high or rising ECLAM score or anti-dsDNA levels (B and E).

Combining both, TM and anti-dsDNA levels, the whole group could be divided into other four subgroups: $\mathrm{G}$ with $\mathrm{TM} \geq 350 \mathrm{ng} / \mathrm{ml}+$ anti-dsDNA $>40 \mathrm{IU} / \mathrm{ml}$ (9 patients), $\mathrm{H}$ with $\mathrm{TM} \geq 350 \mathrm{ng} / \mathrm{ml}$ and anti-dsDNA $\leq 40$ IU/ml (8 patients), I with TM $<50 \mathrm{ng} / \mathrm{ml}$ (12 patients) and anti-dsDNA $>40 \mathrm{IU} / \mathrm{ml}$ and $\mathrm{J}$ with $\mathrm{TM}<50 \mathrm{ng} / \mathrm{ml}$ and anti-dsDNA $\leq 40 \mathrm{IU} / \mathrm{ml}$ (23 patients).

The disease activity index was highest in subgroup $G$ (with both high TM and anti-dsDNA) and differed significantly from the other subgroups, in all cases $\mathrm{p}<0.05$ (Table 3 and Figure 4).

\section{DISCUSSION}

The statistical analysis of the results of the serial follow up of TM levels in SLE shows the correlation between thrombomodulin plasma levels and disease activity index. This correlation seems to be stronger than correlation between anti-dsDNA antibodies and ECLAM index of activity. In some recent studies the thrombomodulin was suggested as the best marker of disease activity in systemic lupus available at present, because its correlation to disease activity index was the strongest from other serological tests (ESR, C3, IgG, anti-dsDNA, ANA, sVCAM-1, sICAM-1, sIL-2R, IL-6, IL-10, sEselectin $)^{6,7}$. However, in some probands with active disease the TM levels stay low also before the administration of therapy. The existence of some mechanism limiting the vascular response in these cases could be one of possible explanations.

This study demonstrates further, that TM levels tend to be lower and without any significant changes during the follow up of stable patients with generally low index of disease activity. This finding corresponds with the results of the French healthy population study, which demonstrated the stable levels of TM in the range between 20 and 60 years ${ }^{8}$. In subgroups with constantly active SLE (or with rising activity) the plasma levels of TM are risen and are significantly different from the inactive patients. In the subgroup of patients with active disease but with decrease in activity index due to the therapy response the thrombomodulin levels has the similar trend as ECLAM index. Significant difference in TM levels between stable SLE patients and subgroup with high activity followed by the good therapeutic response can be seen in the first series of measurement. In the following series difference between these subgroups loses its statistical significance and thrombomodulin levels in both subgroups are very similar. Significant decline in TM plasma levels can be usually observed during first three months of follow up probably due to the effect of therapy.
Similar trend as in the patients divided to subgroups according to clinical activity index could be observed, if the patients population was divided according to the anti-dsDNA antibodies levels into subgroups with low, stable, high and/or rising or decreasing titer of antibodies. However, the differences in TM between these subgroups are statistically weaker. TM plasma concentration expresses as well as anti-dsDNA antibody the disease activity, but their mutual correlation is not strong enough. Plasma levels of TM reflect the fact, that this free molecule is not a product of the autoimmune stimulation like anti-dsDNA, neither plays role in immune complex clearance as complement components, but it is released by endothelial cells injury. Therefore TM as a part of coagulation system could be regarded as a marker independent on immune response ${ }^{2}$.

Combination of two markers, TM and anti-dsDNA, seems to provide more information on the disease and to be more useful disease activity tool than each alone. The subgroup with levels of TM over $50 \mathrm{ng} / \mathrm{ml}$ and positivity of anti-dsDNA antibodies had the highest ECLAM index, statistically different from other subgroups. Patients with both markers low (or negative), the ECLAM index showed the lowest clinical disease activity. In patients with lupus nephritis (documented by histology or evident from the clinical picture) the TM levels were increased corresponding with high disease activity index and significantly higher than in the subgroups with minimal clinical activity. This observation accents the role of endothelial cell damage in glomerulonephritis. Some decline in TM levels was observed after three months period of treatment, but it differed very much among these patients, thus by statistical means the change was not significant from the baseline measurement.

Thrombomodulin is nowadays increasingly used as a marker of endothelial damage in a large number of diseases such as disseminated intravascular coagulation $^{9}$, ulcerative colitis ${ }^{10}$, sepsis ${ }^{11}$, malaria ${ }^{12,13}$, pulmonary hypertension, pre-eclampsia, diabetes mellitus associated micro- or macroangiopathy ${ }^{14,15}$, thromboticthrombocytopenic purpura, adult respiratory distress syndrome, coronary and other atherosclerotic lesions ${ }^{16}$. Increased thrombomodulin levels were also associated with disease activity in vasculitis such as Takayasu's arteriitis, Behçet disease, giant cell arteriitis, polyarteriitis nodosa and Wegener's granulomatosis ${ }^{17}$. Elevation of plasma TM was also reported in some patients with rheumatoid arthritis ${ }^{18}$, Sjögren's syndrome, systemic sclerosis $^{19}$ or dermatomyositis ${ }^{16,20}$.

In SLE patients the positive correlation was reported between TM and disease activity index ${ }^{2,16,21}$, activity of lupus nephritis ${ }^{22,23,24}$ and titer of antiphospholipid antibodies $^{16,20,25}$. Thrombomodulin was suggested as a promising marker of therapeutic response ${ }^{2,6}$. Since lacking international consensus on the normal plasma thrombomodulin levels (the mean values in healthy persons varied according to the assay and standard calibration from $3-50 \mathrm{ng} / \mathrm{ml})^{16}$, it is reasonable to follow-up the 
individual thrombomodulin plasma levels ${ }^{2}$, which could help to predict flare and vascular complications or to monitor the successful therapeutic response.

TM should not be regarded as a single instrument in SLE evaluation and the monitoring of disease activity in SLE still remains based on the careful evaluation of organ systems and on the panel of laboratory tests. Nevertheless, the data of this study as well as other studies show TM as one of the most important marker of SLE activity.

Table 1. Characteristics of subgroups A,B,C, D, E, F, LN in I, II, III. serial measurement

\begin{tabular}{|l|l|l|l|l|}
\hline Subgroup & $\begin{array}{l}\text { ECLAM } \\
\overline{\mathrm{x}}\end{array}$ & $\begin{array}{l}\text { anti-dsDNA Ab } \\
\text { IU/ml, } \overline{\mathrm{x}}\end{array}$ & $\begin{array}{l}\mathrm{C} 3 \\
\overline{\mathrm{x}} \\
\mathrm{g} / \mathrm{l}\end{array}$ & $\begin{array}{l}\mathrm{C} 4 \\
\overline{\mathrm{x}} / 1\end{array}$ \\
\hline A I. & 1.7 & $22.29( \pm 20.0)$ & 0.77 & 0.19 \\
\hline A II. & 1.7 & $10.5( \pm 14.2)$ & 0.76 & 0.18 \\
\hline A III. & 1.8 & $13.25( \pm 10.0)$ & 0.75 & 0.19 \\
\hline B I. & 3.7 & $85.12( \pm 79.1)$ & 0.60 & 0.15 \\
\hline B II. & 4.2 & $109.9( \pm 62.1)$ & 0.60 & 0.14 \\
\hline B III. & 4.4 & $90.37( \pm 62.9)$ & 0.65 & 0.14 \\
\hline C I. & 4.0 & $77.83( \pm 77.8)$ & 0.56 & 0.15 \\
\hline C II. & 3.0 & $57.81( \pm 54.6)$ & 0.61 & 0.16 \\
\hline C III. & 2.4 & $39.91( \pm 21.0)$ & 0.68 & 0.17 \\
\hline D I. & 1.9 & $12.36( \pm 9.2)$ & 0.74 & 0.20 \\
\hline D II. & 1.8 & $15.20( \pm 14.2)$ & 0.75 & 0.19 \\
\hline D III. & 1.9 & $18.58( \pm 17.0)$ & 0.73 & 0.19 \\
\hline E I & 3.4 & $93.00( \pm 70.3)$ & 0.58 & 0.15 \\
\hline E II. & 3.5 & $90.43( \pm 57.6)$ & 0.57 & 0.15 \\
\hline E III. & 3.5 & $104.1( \pm 59.6)$ & 0.57 & 0.15 \\
\hline F I. & 3.7 & $93.40( \pm 66.6)$ & 0.55 & 0.14 \\
\hline F II. & 2.8 & $50.33( \pm 47.0)$ & 0.61 & 0.17 \\
\hline F III. & 2.3 & $31.0( \pm 24.7)$ & 0.65 & 0.16 \\
\hline LN I. & 5.0 & $90.07( \pm 76.5)$ & 0.50 & 0.14 \\
\hline LN II. & 3.3 & $73.53( \pm 60.97)$ & 0.59 & 0.12 \\
\hline LN III. & 3.4 & $75.44( \pm 55.0)$ & 0.58 & 0.15 \\
\hline
\end{tabular}

A - stabilized, B high and/or rising activity, C - decreasing activity according to ECLAM system; D stabilized, E high and/or rising, F decreasing levels of anti-dsDNA antibodies, LN patients with lupus nephritis
Table 2. Thrombomodulin levels in group A, B, C, D, E, F and LP in I, II, III. serial measurement in the serial measurement $(\mathrm{ng} / \mathrm{ml})$

\begin{tabular}{|l|l|l|l|l|}
\hline $\begin{array}{l}\text { Subgroup }+ \\
\text { series of } \\
\text { measurement }\end{array}$ & $\begin{array}{l}(\mathrm{tm}) \\
\overline{\mathrm{x}}\end{array}$ & $\mathrm{SD}$ & $\begin{array}{l}\text { median } \\
\mathrm{M}\end{array}$ & $\begin{array}{l}\mathrm{min}- \\
\mathrm{max}\end{array}$ \\
\hline A I. & 32.0 & 11.56 & 30 & $7-62$ \\
\hline A II. & 37.9 & 12.00 & 35 & $20-69$ \\
\hline A III. & 36.5 & 6.8 & 34 & $19-44$ \\
\hline B I. $*$ & 51.9 & 49.0 & 47 & $25-146$ \\
\hline B II. * & 72.66 & 44.00 & 63.5 & $28-175$ \\
\hline B III. * & 98.14 & 71.4 & 63 & $27-202$ \\
\hline C I. $*$ & 62.8 & 49.0 & 32.5 & $25-181$ \\
\hline C II. \# & 38.75 & 21.30 & 31 & $24-87$ \\
\hline C III. \# & 40.45 & 17.15 & 35 & $20-95$ \\
\hline D I. & 33.52 & 12.73 & 31 & $7-66$ \\
\hline D II. & 47.0 & 20.08 & 39 & $32-69$ \\
\hline D III. & 41 & 9.37 & 41 & $33.6-66$ \\
\hline E I. * & 56.7 & 41.10 & 32.0 & $25-146$ \\
\hline E II. & 61.88 & 41.5 & 40 & $30-175$ \\
\hline E III. * & 79.8 & 56.4 & 47.5 & $31-202$ \\
\hline F I. & 58.0 & 53.00 & 29.5 & $26-181$ \\
\hline F II. & 34.5 & 10.0 & 31 & $24-44$ \\
\hline F III. \# & 31.25 & 5.12 & 39 & $24-44$ \\
\hline LN I. * & 78.33 & 50.04 & 100 & $25-146$ \\
\hline LN II. * & 66.33 & 42.29 & 60 & $28-175$ \\
\hline LN III. * & 88.66 & 60.1 & 43 & $27-202$ \\
\hline & & & & \\
\hline
\end{tabular}

A - stabilized, B high and/or rising activity, C - decreasing activity according to ECLAM system; D stabilized, E high and/or rising, F decreasing levels of anti-dsDNA antibodies, LN patients with lupus nephritis

ANOVA statistic, $\mathrm{p}<0.05$

* statistically significant difference between first, second and third measurement in subgroups $\mathrm{B}, \mathrm{LN}$ and first measurement in $\mathrm{C}$ (high disease activity) on one side and subgroup A or D (low disease activity) on the other side

\# statistical significant difference between second and third measurements in subgroups $\mathrm{C}$ and $\mathrm{F}$ (declining activity) on one side and subgroup B and E (high or rising activity) on the other side.

Table 3. Comparison of ECLAM score in subgroups G, H, I and J

\begin{tabular}{|l|l|l|l|l|}
\hline Subgroup & $\frac{\text { ECLAM }}{\mathrm{x}}$ & $\mathrm{SD}$ & median & Min-max \\
\hline $\mathrm{G}{ }^{*}$ & 4.3 & 1.9 & 4 & $2-7$ \\
\hline $\mathrm{H}$ & 2.5 & 1.19 & 2.5 & $1-4$ \\
\hline $\mathrm{I}$ & 3.1 & 0.71 & 3 & $2-5$ \\
\hline $\mathrm{J} \#$ & 1.9 & 0.96 & 2 & $1-4$ \\
\hline
\end{tabular}

$\mathrm{G}$ with $\mathrm{TM} \geq 350 \mathrm{ng} / \mathrm{ml}+$ anti-dsDNA $>40 \mathrm{IU} / \mathrm{ml}, \mathrm{H}$ with $\mathrm{TM} \geq 350 \mathrm{ng} / \mathrm{ml}$ and anti-dsDNA L40 IU/ml, I with $\mathrm{TM}<50 \mathrm{ng} / \mathrm{ml}$ and anti-dsDNA $>40 \mathrm{IU} / \mathrm{ml}$ and $\mathrm{J}$ with $\mathrm{TM}<50 \mathrm{ng} / \mathrm{ml}$ and anti-dsDNA $\leq 40 \mathrm{IU} / \mathrm{ml}$ ) ANOVA statistics $(\mathrm{p}<0.05)$

* Significant difference between the subgroup G and subgroups H, I, $\mathrm{J}$.

\# Significant difference between the subgroup J and I. 

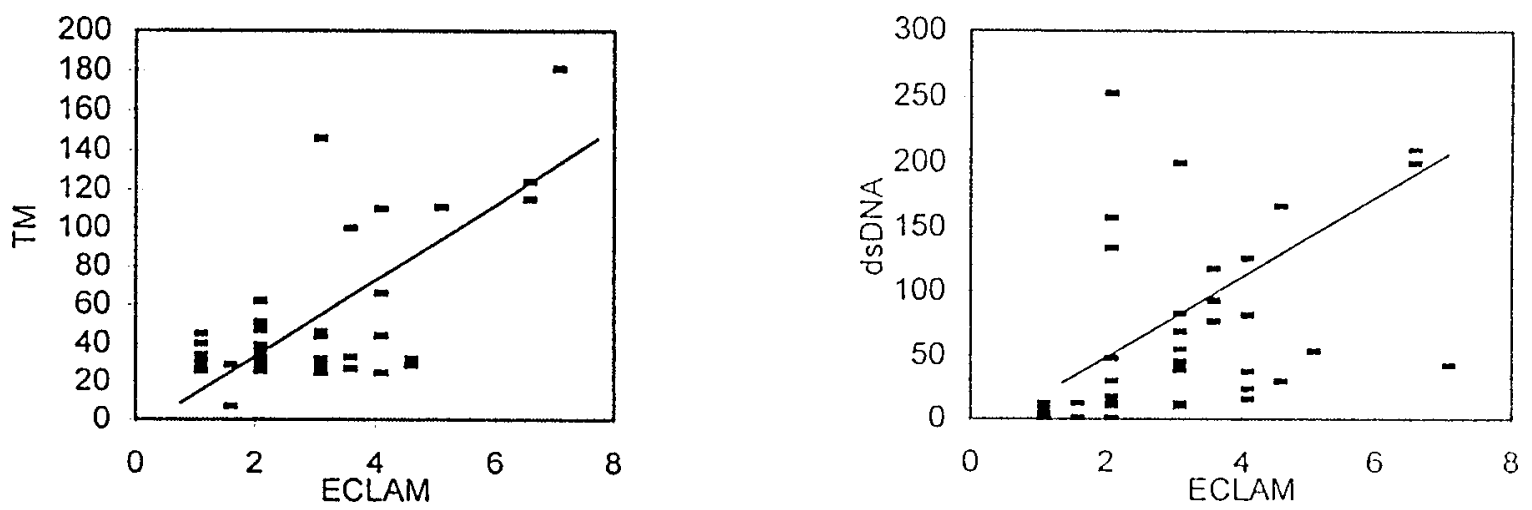

Fig. 1 Correlations between ECLAM system and thrombomodulin and anti-dsDNA levels in the whole group of patients $(\mathrm{n}=52)$

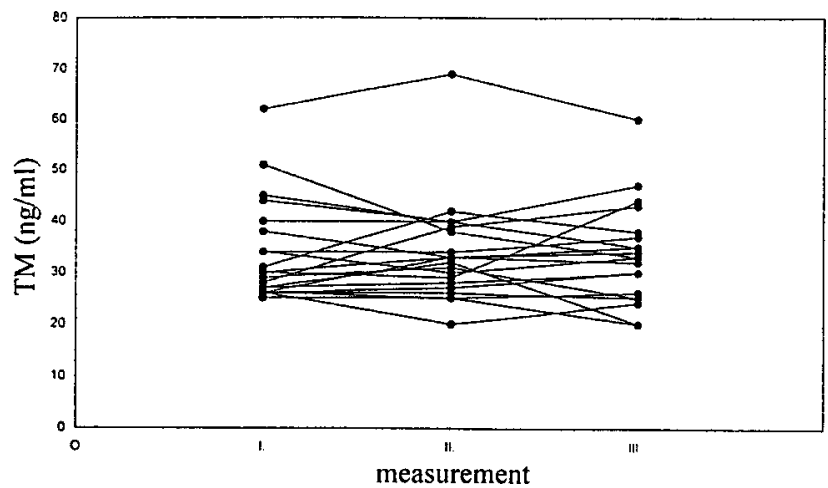

Fig. 2A Development of thrombomodulin levels in patients with low stable ECLAM disease activity index $(n=22)$

B

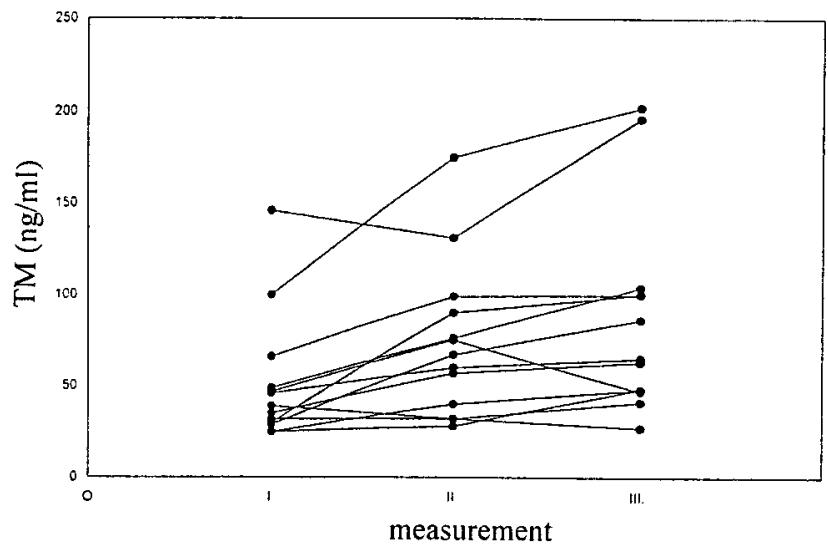

Fig. 2B Development of thrombomodulin levels in patients with high or rising ECLAM disease activity index $(\mathrm{n}=12)$

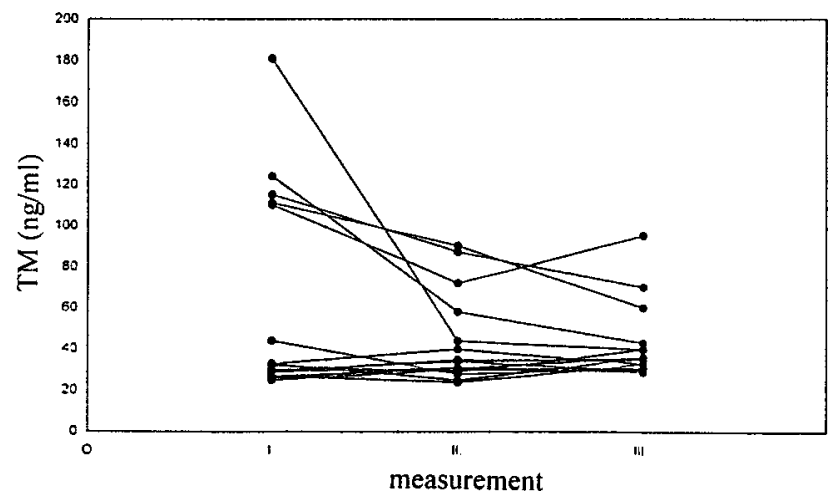

Fig. 2C Development of thrombomodulin levels in patients with declining ECLAM disease activity index $(\mathrm{n}=18)$

$\mathrm{D}$

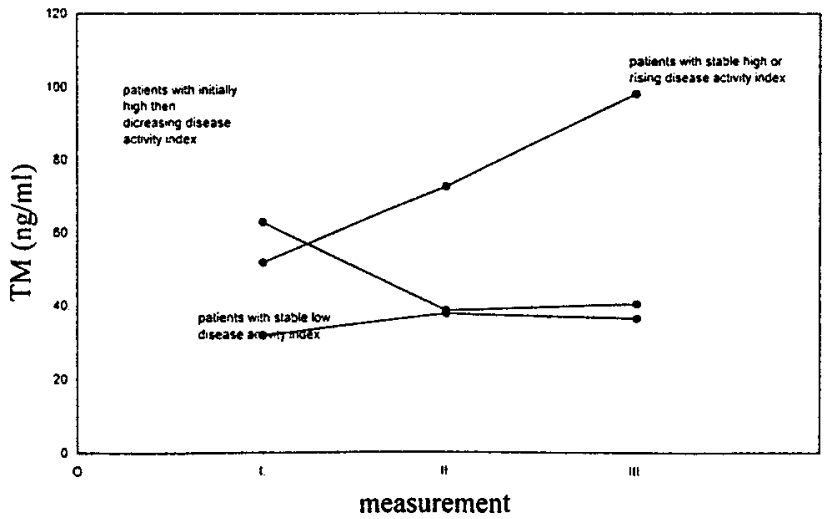

Fig. 2D Trend of mean thrombomodulin levels in subgroups A, B, C (A low stable, B high and/or rising, $\mathrm{C}$ declining ECLAM diseases activity index) 


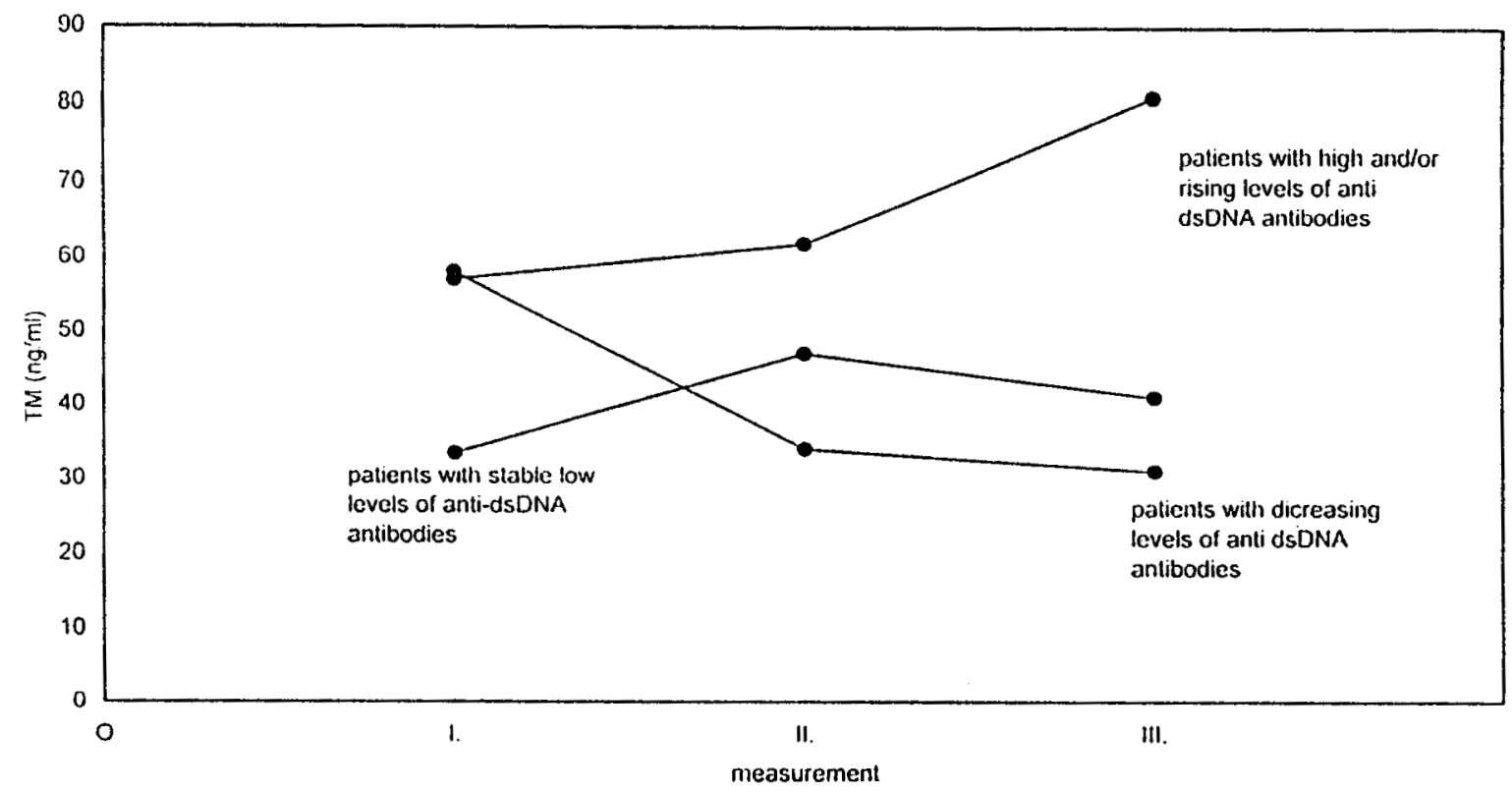

Fig. 3 Trend of mean thrombomodulin levels in subgroups D, E, F (D - low stable, E high and/or rising, F declining anti-dsDNA levels)

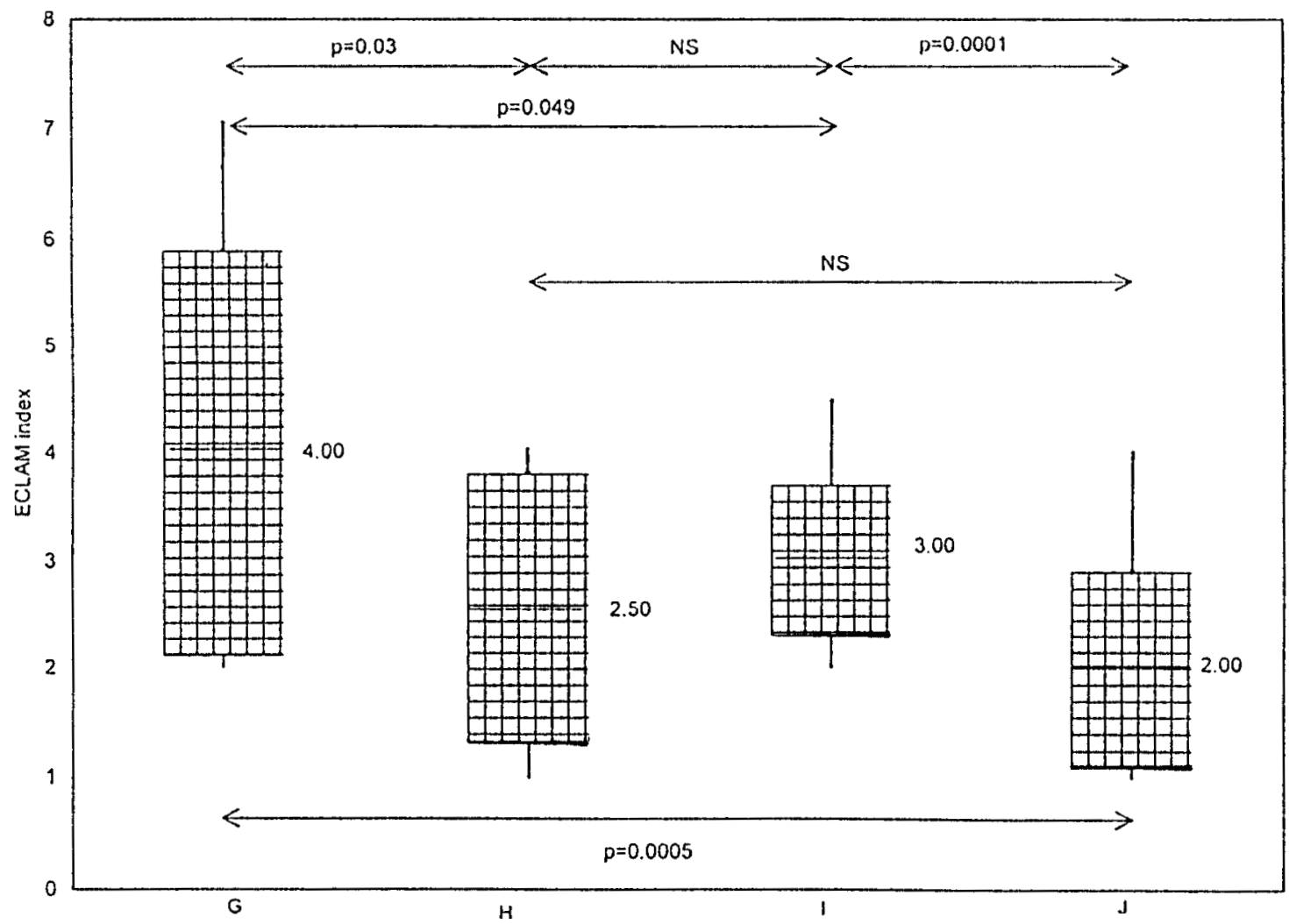

Fig. 4 ECLAM index in subgroups G (high TM/+dsDNA), H (high TM/-dsDNA), I (low TM/+dsDNA), J (low TM/-dsDNA antibodies). Graph shows the median, maximal and minimal values and standard deviation of ECLAM index and statistical diferences amony subgroups. NS - non significant. 


\section{ACKNOWLEDGMENT}

The financial support by IGA CR No NK 4616-3.

\section{REFERENCES}

1. Esmon, C. T. (1995) Thrombomodulin as a model of molecular mechanisms that modulate protease specificity and function at vessel surface. FASEB J., 9, 946-955.

2. Boehme, M. W., Nawroth, P. P., Kling, E. et al. (1994) Serum thrombomodulin. A novel marker of disease activity in systemic lupus erythematosus. Arthritis Rheum., 37, 572-577.

3. Kotajima, L., Aotsuka, S., Sato, T. (1997) Clinical significance of serum thrombomodulin levels in patients with systemic rheumatic diseases. Clin. Exp. Rheumatol., 15, 59-65.

4. Bencivelli, W., Vitali, C., Isenberg, D. A. et al. and European Consensus Study Group for Disease Activity in SLE (1992) Disease activity in SLE: Report of the consensus study group of the European workshop for rheumatology research. III. Development of the computerised clinical chart and its appplication to the comparison of different indices of disease activity. Clin. Exp. Rheumatol., 10, 549-554.

5. Tan, E. M., Cohen, A. S., Fries, J. F. et al. (1982) The 1982 revised criteria for the classification of systemic lupus erythmatosus. Artritis Rheum., 25, 1271-1277.

6. Boehme, M. W., Raeth, U., Galle, P. R. et al. (2000) Serum thrombomodulin-a reliable marker of disease activity in systemic lupus erythematosus (SLE): advantage over established serological parameters to indicate disease activity. Clin. Exp. Immunol., 119, 189-195.

7. Witte, T., Hartung, K., Sachse, C. et al. (1999) Thrombomodulin in systemic lupus erythematosus: association with clinical and laboratory parameters. Rheumatol. Int., 19, 15-18.

8. Boffa, M. C., Aurosseau, K., Wiesel, M. L. et al. (1991) Variations of plasma thrombomodulin level due to sex and age. Blood, 78, S1, 221.

9. Asakura, H., Jokaji, H., Saito, M. et al. (1991) Plasma levels of soluble thrombomodulin increase in cases of disseminated intravascular coagulation with organ failure. Am. J. Hematol., 38, 281-287.

10. Boehme, M. W., Autschbach, F., Zuna, I. et al. (1997) Elevated serum levels and reduced immunohistochemical expression of thrombomodulin in active ulcerative colitis. Gastroenterology, 113, 107-117.

11. Takakuwa, T., Endo, S., Nakae, H. et al. (1994) Plasma levels of TNF-alpha, endothelin-1 and thrombomodulin in patients with sepsis. Pharmacology, 84, 261-269.
12. Boehme, M. W., Werle, E., Krommorell, B. et al. (1994) Serum levels of adhesion molecules and thrombomodulin as indicator of vascular injury in severe Plasmodium falciparum malaria. Clin. Invest., 72, 598-603.

13. Hemmer, C. J., Bierhaus, A., Riedesel, J. et al. (1994) Elevated thrombomodulin plasma levels as a result of endothelial involvement in Plasmodium falciparum malaria. Thromb. Haemost., 72, 457-464.

14. Magriples, U., Hsu, C. D., Chan, D. W. et al. (1997) Circulating thrombomodulin levels and clinical correlates in pregnant diabetics. Am. J. Perinatol., 14, 605-608.

15. Gruden, G., Pagano, G., Romagnoli, R. et al. (1995) Thrombomodulin levels in insulin-dependent diabetic patients with microalbuminuria. Diabetic Medicine, 12, 258-260.

16. Boffa, M.C., Karmochkine, M. (1998) Thrombomodulin: an overview and potential implications in vascular disorders. Lupus, 7, S120-125.

17. Boehme, M. W., Schmitt, W. H., Youinou, P. et al. (1996) Relevance of elevated serum thrombomodulin and soluble E-selectin in patients with Wegener's granulomatosis and systemic vasculitides. Am. J. Med., 101, 387-394.

18. Ichikawa, Y., Takaya, M., Shimizu, H. et al. (1993) Thrombomodulin levels in the plasma and joint fluid from patients with rheumatoid arthritis. Tokai J. Exp. Clin. Med., 18, 123-126.

19. Mizutani, H., Hayashi, T., Nouchi, N. et al. (1996) Increased endothelial and epidermal thrombomodulin expression and plasma thrombomodulin level in progressive systemic sclerosis. Acta Med. Okayama, 50, 293-297.

20. Ohdama, S., Yoshizawa, Y., Kubota, T. et al. (1994) Plasma thrombomodulin as an indicator of thromboembolic disease in systemic lupus erythematosus. Int. J. Cardiol., 47, S, 1-6.

21. Hsu, C. D., Chan, D. W., Iriye, B. et al. (1995) Plasma thrombomodulin levels in women with systemic lupus erythematosus. Am. J. Perinatol., 12, 27-29.

22. Tomura, S., Deguchi, F., Ando, R. et al. (1994) Plasma thrombomodulin in primary glomerular disease and lupus glomerulonephritis. Nephron, 67, 185-189.

23. Tomura, S., Deguchi, F., Marumo, F. et al. (1994) Enhanced presence of thrombomodulin in the glomeruli of lupus glomerulonephritis. Clin. Nephrol., 41, 205210.

24. Kawakami, M., Kitani, A., Hara, M. et al. (1992) Plasma thrombomodulin and alpha 2-plasmin inhibitor-plasmin complex are elevated in active systemic lupus erythematosus. J. Rheumatol., 19, 1704-1709.

25. Kiraz, S., Ertenli, I., Benekli, M. et al. (1999) Clinical significance of hemostatic markers and thrombomodulin in systemic lupus erythematosus: evidence for a prothrombotic state. Lupus, 8 , 737-741. 